\title{
The Effect of Vitamin D Deficiency on the Severity of Bronchiolitis in Infants
}

\section{Süt Çocuklarında Vitamin D Eksikliğinin Bronșiolit Ciddiyeti Üzerine Etkisi}

\author{
Meltem Erol, Hüseyin Kaya, Özlem Bostan Gayret, Özgül Yiğit, Şahin Hamilçıkan, Emrah Can \\ Bağcılar Training and Research Hospital, Clinic of Pediatrics, Istanbul, Turkey
}

\begin{abstract}
Aim: This study was conducted to investigate the effect of vitamin D deficiency on the severity of bronchiolitis in infants who were hospitalized for treatment.

Materials and Methods: The infants who were followed up in our hospital and monitored due to acute bronchiolitis within a 0 to 24-month period were included in the study. The cases were evaluated by the clinical characteristics scoring system and divided into two groups (mild and moderate-severe). A questionnaire filled in by the mothers of the children to question the factors associated with vitamin D. The vitamin D levels of the cases, their clinical histories, and histories of taking vitamin D were examined.

Results: The number of patients with a vitamin D level $<20 \mathrm{ng} / \mathrm{mL}$ in the moderate-severe disease group was higher than the number in the mild disease severity group $(p<0.05)$. No difference was detected in the number of patients who received vitamin $\mathrm{D}$ prophylaxis between the moderate-severe and mild disease severity groups $(p>0.05)$. The number of patients with vitamin $D$ level $<20 \mathrm{ng} / \mathrm{mL}$ was higher in the hospitalized group than in the non-hospitalized group $(p<0.05)$. There was no difference in the number of patients that received vitamin $\mathrm{D}$ prophylaxis between the hospitalized and the non-hospitalized groups ( $p>0.05)$.

Conclusion: Vitamin D deficiency in infants is associated with increased severity of bronchiolitis and hospitalization.

Keywords: Bronchiolitis, vitamin D deficiency, infant
\end{abstract}

ÖZ

Amaç: Bu çalışma, bronşiyolit nedeniyle hastaneye yatırllarak tedavi edilen süt çocuklarında vitamin $\mathrm{D}$ eksikliğinin bronşiyolit ciddiyeti üzerine etkisinin araştırıması amacılla yapılmıştır.

Gereç ve Yöntemler: Hastanemizde 0 ile 24 aylık dönem içinde akut bronşiyolit nedeniyle izlenen süt çocukları çalışmaya dahil edilmiştir. Olgular klinik özellikleri skorlama sistemi ile değerlendirilerek iki gruba (hafif ve ortaağır) ayrılııs, olguların annelerine D vitamini ile ilişkili faktörleri sorgulayan anket formu uygulanmışır. Olguların klinik öyküleri, D vitamini alma öyküleri ve $D$ vitamini düzeyleri incelenmiştir.

Bulgular: Orta ve ağır derecedeki hastalık grubunda $D$ vitamini düzeyi $<20$ $\mathrm{ng} / \mathrm{mL}$ olan hastaların sayıs hafif şiddette hastalık grubundakilerin sayısından daha yüksekti $(p<0,05)$. Hafif derecedeki hasta grubu ile orta-ağır derecedeki hasta grubunda D vitamini profilaksi alan hastaların sayısı arasında anlamlı farklılık saptanmadı $(p>0,05)$. Hastaneye yatırlan hastalar arasında D vitamini düzeyi $<20 \mathrm{ng} / \mathrm{mL}$ olan hastaların sayısı hastaneye yatııımayan hastalara göre daha yüksekti $(p<0,05)$. D vitamini profilaksisi alan hastaların sayısı açısından hastaneye yatırılan grup ile hastaneye yatııılmayan grup arasında anlamlı fark saptanmadı $(p>0,05)$.

Sonuç: Süt çocuklarında D vitamini eksikliği, artmış bronşiyolit şiddeti ve hastaneye yatış ile iliş̧ilidir.

Anahtar Kelimeler: Bronşiyolit, D vitamini eksikliği, süt çocuğu

rates of vitamin D deficiency within infants. Vitamin D has been demonstrated to play roles in both immune system activation and the prevention of infections by microorganisms. An increased risk of respiratory system

Recently, the harmful effects of pathogens that cause bronchiolitis have strengthened, possibly due to increasing 
diseases has been demonstrated in the first three months in infants with low vitamin $D$ levels in the cord blood at birth (1). Recent studies have defined vitamin D deficiency as a serum 25-hydroxyvitamin D [25(OH)D] level equal to or less than $20 \mathrm{ng} / \mathrm{mL}$, whereas vitamin $D$ insufficiency is defined as a serum level between 21 and $29 \mathrm{ng} / \mathrm{mL}$. The lowest 25(OH) $\mathrm{D}$ level that will not activate parathormone is $30 \mathrm{ng} / \mathrm{mL}$ (75 $\mathrm{nmol} / \mathrm{L})$; therefore, a sufficient vitamin $D$ level is accepted as $>30 \mathrm{ng} / \mathrm{mL}$ (75 nmol/L) (2-4). Vitamin D effects susceptibility to infections that trigger wheezing at an early age and the response to this process. The relationship between serum vitamin $\mathrm{D}$ levels and respiratory tract infections was shown in the National Health and Nutrition Examination Survey (NHANES) III study, where this relationship was more evident in patients with asthma and chronic obstructive pulmonary disease (5). In another population-based study, a strong relationship was found between vitamin D serum levels and forced expiratory volumes in 1 second (6). Respiratory tract infections are frequent causes of asthma exacerbation among children and adults, and are associated with low vitamin $D$ levels (7). The most frequently reported factors that result in exacerbation are rhinoviruses and corona viruses (8). In a recent study, vitamin D serum levels were shown to be inversely related to the total immunoglobulin $\mathrm{E}$ concentration and eosinophil numbers, and hospitalizations were rarer among patients with high vitamin $D$ levels during the preceding one year period. The relationship between a high vitamin $D$ level and a decrease in the need for antiinflammatory treatment was shown in the same study (9).

\section{Materials and Methods}

\section{Study Population}

This single center prospective study was conducted at Bağcılar Training and Research Hospital, Clinic of Pediatrics in Istanbul, Turkey between January and April 2015.

Bronchiolitis was diagnosed in children aged 1-24 months in accordance with the study's inclusion criteria; a total of 102 children receiving treatment at the hospital were included. Children with known chronic lung disease, heart disease, recurrent lower respiratory tract infection, growth retardation, and a history of premature birth were excluded. The diagnosis of bronchiolitis was made during the medical examination of the patients, with regard to complaints of coughing, and respiratory distress alongside clinical findings such as rales and rhonchi.

The patient data were obtained from the history and file records. The history of bronchiolitis, history of hospitalization, use and duration of vitamin D prophylaxis in infancy were recorded according to the information obtained from the mother. The assessment of disease severity was determined in accordance with the Turkish Thoracic Society guidelines for acute bronchiolitis (10). The patients were divided into two groups (mild and moderate-severe) according to their clinical conditions. The classification was based on the general condition of the patient, breaths per minute, the presence of apnea, pulse rate, oxygen saturation and the existence of chest retraction (Table I).

The questionnaire forms were prepared. The form was filled in according to the definitions of the mothers during examination. The results of these questionnaire forms were given in Table II. Infants who had used vitamin D or vitamin preparations containing vitamin $\mathrm{D}$ for more than six months were accepted to have used vitamin D regularly.

\begin{tabular}{|l|l|l|l|}
\hline \multicolumn{4}{|l|}{ Table I. Assessment of bronchiolitis severity } \\
\hline & Mild & Moderate & Severe \\
\hline Apnea & - & - & + \\
\hline Breaths/minute & $<50$ & $50-70$ & $>70$ \\
\hline Pulse/minute & $<140$ & $140-160$ & $>160$ \\
\hline Retraction & Mild & Moderate & Severe \\
\hline $\mathrm{SaO}_{2}$ & $>93 \%$ & $86-92 \%$ & $<85 \%$ \\
\hline Cyanosis & - & - & + \\
\hline $\mathrm{SaO}_{2}$ : Arterial blood oxygen saturation & & \multicolumn{5}{l}{} \\
\hline
\end{tabular}

\section{Laboratory Measurements}

Blood samples were taken from all the infants to study the serum vitamin D levels. The blood was centrifuged for 5 minutes at $3000 \mathrm{rpm}$, and the serum was separated. Each serum sample was covered with dark carbon paper to prevent light permeation and then frozen and stored at -30 degrees $\mathrm{C}$ prior to the analysis. The vitamin D levels were examined using the electro chemiluminescence enzyme immuno assay method (ADVIA Centaur, USADPC Co., USA).

The study protocol was approved by the Research Ethics Committee of Bağcılar Training and Research Hospital in accordance with the Declaration of Helsinki (approval number: 2014-300). Informed consent was obtained from the parents of all study participants.

\section{Statistical Analysis}

The mean, standard deviation, median lowest and highest values, frequency and ratio values were used as the descriptive statistics of the data. The distribution of the variables was measured using the Kolmogorov-Smirnov test. The Mann-Whitney $U$ test was used in the analysis of the qualitative data together with the chi-square; when the chi-square test conditions were not met, Fisher's test was used. The Spearman correlation analysis was used to assess correlations.

\section{Results}

The demographic data from the infants included in the study are presented in Table II. No significant difference in disease severity was detected between the groups in terms of gender and age distribution. The vitamin $\mathrm{D}$ concentration 
was significantly lower in the moderate-severe group. The number of patients with vitamin D concentrations $<20 \mathrm{ng} / \mathrm{mL}$ in the moderate-severe disease group was higher than the number in the mild disease severity group. No difference was detected in the number of patients who received vitamin $D$ prophylaxis between the moderate-severe and mild disease severity groups (Table III).

The number of patients between 0 and 2 years of age was higher in the hospitalized group compared to the nonhospitalized group. There was no difference in the gender distribution between the hospitalized and non-hospitalized groups, but the vitamin D concentration was lower in the hospitalized group. The number of patients with vitamin D concentrations $<20 \mathrm{ng} / \mathrm{mL}$ in the hospitalized group was higher than that in the non-hospitalized group. No difference was detected between the rates of patients that received vitamin D prophylaxis in the hospitalized and non-hospitalized groups. There was no significant correlation between the vitamin $\mathrm{D}$ level and the hospitalization durations and patient age. The gender distribution and age distribution were not significantly different between the moderate-severe and mild disease severity groups. However, the vitamin D concentration was significantly lower in the moderate-severe disease severity group $(p<0.05)$. The number of patients that received vitamin $\mathrm{D}$ prophylaxis was not significantly different

\begin{tabular}{|c|c|c|c|}
\hline Generally characteristics & & & \\
\hline Age (mean \pm standard deviation) & \multicolumn{3}{|c|}{$5.8 \pm 4.76$ (year) } \\
\hline \multirow[t]{3}{*}{ Age } & $0-3$ months & 47 & $27.7 \%$ \\
\hline & 4-6 months & 12 & $33.0 \%$ \\
\hline & $6-24$ months & 43 & $32.1 \%$ \\
\hline Vitamin D level (ng/mL) & \multicolumn{3}{|c|}{$23.24 \pm 13.6$} \\
\hline \multirow[t]{6}{*}{ Vitamin D (ng/mL) } & $0-5$ & 10 & $9.8 \%$ \\
\hline & $5-10$ & 14 & $12.5 \%$ \\
\hline & $10-15$ & 6 & $6.3 \%$ \\
\hline & $15-20$ & 11 & $10.7 \%$ \\
\hline & $20-25$ & 17 & $17.0 \%$ \\
\hline & $>30$ & 44 & $43.8 \%$ \\
\hline Duration of hospitalization (days) & \multicolumn{3}{|c|}{$4.15 \pm 3.29$} \\
\hline \multirow[t]{2}{*}{ Gender } & Girl & 44 & $40.0 \%$ \\
\hline & Boy & 58 & $58.0 \%$ \\
\hline \multirow[t]{2}{*}{ Hospitalization } & Yes & 75 & $67.0 \%$ \\
\hline & No & 37 & $33.0 \%$ \\
\hline \multirow[t]{2}{*}{ Bronchiolitis severity } & Mild & 58 & 56.9 \\
\hline & Moderate-severe & 44 & 43.1 \\
\hline \multirow[t]{2}{*}{ Vitamin D prophylaxis } & Received & 88 & $84.8 \%$ \\
\hline & No received & 14 & $15.2 \%$ \\
\hline
\end{tabular}

between these two groups. The vitamin D concentration was significantly lower in the hospitalized group than in the nonhospitalized group $(p<0.05)$.

\section{Discussion}

Vitamin D plays a role in immune system activation, it helps to prevent infections caused by microorganisms. Studies have shown a relationship between the severity of bronchiolitis, increased hospitalization, and vitamin D deficiency (11). In this study, we investigated the relationship between vitamin D deficiency and bronchiolitis severity, and found that vitamin D levels are very important for infants with bronchiolitis.

Many studies have proposed that vitamin D concentration decreases due to the decrease in sunlight during the winter months, resulting in a related decrease in immune functions and sensitivity to influenza infections $(12,13)$.

The study by Mansbach and Camargo (12) showed that the wheezing rate was increased in infants of mothers who had vitamin $D$ deficiency during pregnancy. An increased risk of respiratory system diseases was observed in the first three months in infants with low vitamin $D$ concentration in the umbilical cord blood (14).

In the hospital-based case control study performed by Wayse et al. (15), the authors concluded that insufficient breast milk intake and subclinical vitamin $D$ deficiency in the first 4 months of life constituted a significant risk factor for severe lower respiratory tract diseases.

Infections are the most frequent causes of morbidity and mortality among children worldwide. The relationship between insufficient vitamin D levels and respiratory tract infections in children and/or hospitalization has been shown

\begin{tabular}{|c|c|c|c|c|c|c|}
\hline & & & ate- & Mil & & $p$ \\
\hline \multirow[t]{3}{*}{ Age } & $0-3$ months & 26 & $39 \%$ & 21 & $18.9 \%$ & \multirow[t]{3}{*}{0.07} \\
\hline & 4-6 months & 8 & $25 \%$ & 4 & $39.6 \%$ & \\
\hline & 6-24 months & 19 & $36 \%$ & 24 & $41.5 \%$ & \\
\hline \multirow[t]{2}{*}{ Gender } & Girl & 19 & $43 \%$ & 28 & $41 \%$ & \multirow[t]{2}{*}{0.609} \\
\hline & Boy & 25 & $57 \%$ & 30 & $59 \%$ & \\
\hline \multicolumn{2}{|c|}{ Vitamin $D(\mathrm{ng} / \mathrm{mL})$} & \multicolumn{2}{|c|}{$15.5 \pm 11.4$} & \multicolumn{2}{|c|}{$26.0 \pm 11.8$} & 0.0001 \\
\hline \multirow[t]{6}{*}{ Vitamin D } & $0-5$ & 8 & $20 \%$ & 2 & $3 \%$ & \multirow[t]{6}{*}{0.0001} \\
\hline & $5-10$ & 11 & $20 \%$ & 3 & $7 \%$ & \\
\hline & $10-15$ & 4 & $11 \%$ & 2 & $3 \%$ & \\
\hline & $15-20$ & 3 & $9 \%$ & 8 & $12 \%$ & \\
\hline & $20-25$ & 4 & $14 \%$ & 13 & $19 \%$ & \\
\hline & $>30$ & 6 & $25 \%$ & 38 & $56 \%$ & \\
\hline \multirow{2}{*}{$\begin{array}{l}\text { Vitamin D } \\
\text { prophylaxis }\end{array}$} & $(+)$ & 35 & $80 \%$ & 53 & $91 \%$ & \multirow[t]{2}{*}{0.08} \\
\hline & $(-)$ & 9 & $20 \%$ & 5 & $9 \%$ & \\
\hline
\end{tabular}


in many epidemiological studies. Najada et al. (16) also reported a high incidence of nutritional rickets among infants hospitalized due to respiratory tract diseases.

In this study, the rate of the patients between the ages 0 and 2 years was significantly higher in the hospitalized group than in the non-hospitalized group. The gender distribution did not exhibit significant differences between the hospitalized and non-hospitalized patients. The vitamin D concentration was significantly lower in the hospitalized group, but the number of patients with vitamin $D<20 \mathrm{ng} / \mathrm{mL}$ in this group was significantly higher than in the non-hospitalized group. The number of patients that received vitamin $D$ prophylaxis in the hospitalized and non-hospitalized groups was not significantly different.

According to the NHANES data, the frequency of upper respiratory tract infections in patients with serum vitamin $\mathrm{D}<25 \mathrm{nmol} / \mathrm{L}$ was much higher in patients with asthma compared to those without (5). The relationship between vitamin $D$ and asthma has been known for a long time. Although the mechanism is not known, new studies have found an association between high vitamin D levels and better lung functions, lower respiratory tract hypersensitivity and increased glucocorticoid responses (17).

In a case-control study, the vitamin D level in newborns taken to the intensive care unit due to lower respiratory tract infections was demonstrated to be significantly lower compared to healthy infants in the same age group. Additionally, the vitamin D concentration of the mothers was lower compared to the control group (18).

The mechanism by which vitamin $D$ affects the immune system is not known. Viral infections are observed more frequently than bacterial infections in patients with vitamin $D$ deficiency. Therefore, the relationship between vitamin $D$ and immune functions shows the importance of supplementation in the pediatric population (19). In another study performed by Karatekin et al. (20), vitamin D concentrations were examined in the sera of newborns that did not have rickets with a lower respiratory tract infection (LRTI) diagnosis and their mothers. Based on the results, the risk of damage due to LRTI was increased in newborns with a subclinical vitamin $\mathrm{D}$ deficiency. The strong positive correlation between the vitamin $\mathrm{D}$ concentrations of the newborns and their mothers showed that sufficient vitamin D supplementation should be emphasized during pregnancy in winter months $(19,20)$.

A large number of studies have proposed that vitamin $D$ reduces the risk of respiratory tract infections in children (13). In one study, a 13-fold higher risk was found in Ethiopian children younger than 5 years of age whose vitamin D deficiency was shown clinically (21). In a study performed in Yemen, a 50\% vitamin D deficiency was found in children who were admitted (22).

The gender and age distributions were not significantly different in the moderate-severe and mild disease severity groups in this study, but the vitamin D concentration was significantly lower in the moderate-severe disease group. Also the number of patients with vitamin D level $<20 \mathrm{ng} / \mathrm{mL}$ in this group was significantly higher. There was no significant difference in the number of patients who received vitamin $D$ prophylaxis between the two groups.

Studies have demonstrated a role for vitamin D in the expression of the human cathelicidin antimicrobial peptide, which plays a role in host defense against respiratory tract pathogens. These studies showed that the risk of respiratory system infection was increased in subjects with vitamin D deficiency. This increased risk contributes to the increase in the wheezing incidence in children and the exacerbation of asthma in adults. Vitamin D plays a modulator role in regular $\mathrm{T}$ cell functions and interleukin-10 production. Therefore, epidemiological and randomized studies are needed in the future to better understand the role of vitamin $D$ in respiratory infections and asthma (8). In conclusion, our study showed that the decreased vitamin $D$ levels in infants with bronchiolitis were associated with bronchiolitis severity.

\section{Ethics}

Ethics Committee Approval: The study was approved by the Bağcılar Training and Research Hospital Local Ethics Committee (Approval number: 2014-300), Informed Consent: Consent form was filled out by all participants.

Peer-review: External and internal peer-reviewed.

\section{Authorship Contributions}

Surgical and Medical Practices: Meltem Erol, Özlem Bostan Gayret, Özgül Yiğit, Concept: Meltem Erol, Özlem Bostan Gayret, Design: Meltem Erol, Hüseyin Kaya, Şahin Hamilçıkan, Emrah Can, Data Collection or Processing: Hüseyin Kaya, Özgül Yiğit, Şahin Hamilçıkan, Analysis or Interpretation: Meltem Erol, Hüseyin Kaya, Emrah Can, Literature Search: Meltem Erol, Hüseyin Kaya, Özlem Bostan Gayret, Özgül Yiğit, Şahin Hamilçıkan, Writing: Meltem Erol.

Conflict of Interest: No conflict of interest was declared by the authors.

Financial Disclosure: The authors declared that this study received no financial support.

\section{References}

1. Meissner HC. Viral Bronchiolitis in Children. N Engl J Med 2016;37:62-72.

2. Holick MF. Vitamin D: a D-Lightful Health perspective. Nutr Rev 2008;66(10 Suppl 2):S182-94.

3. Dong $Y$, Pollock N, Stallman-Jorgensen IS, et al. Low 25-hydoxyvitamin D levels in adolescents: race, season, adiposity, physical activity, and fitness. Pediatrics 2010;125:1104-11.

4. Holick MF The D-lemma: to screen or not to screen for 25-hydroxyvitamin D concentrations. Clin Chem 2010;56:729-31.

5. Searing DA, Leung DY. Vitamin D in atopic dermatitis, asthma and allergic diseases. Immunol Allergy Clin North Am 2010;30:397-409.

6. Burns JS, Dockery DW, Neas LM, et al. Low dietary nutrient intakes and respiratory health in adolescents. Chest 2007;132:238-45. 
7. Ginde AA, Mansbach JM, Camargo CA Jr. Association between serum 25-hydroxyvitamin $D$ level and upper respiratory tract infection in the Third National Health and Nutrition Examination Survey. Arch Intern Med 2009;169:384-90.

8. Nicholson KG, Kent J, Ireland DC. Respiratory viruses and exacerbations of asthma in adults. BMJ 1993;307:982-6.

9. Dougherty $\mathrm{RH}$, Fahy JV. Acute exacerbations of asthma: epidemiology, biology and The exacerbation-prone phenotype. Clin Exp Allergy 2009;39:193-202.

10. Yalçın E, Karadağ B, Uzuner N, ve ark. Türk toraks derneği akut bronşiyolit tanı ve tedavi uzlaşı raporu. Türk Toraks Dergisi 2009;10;sup1:3-7.

11. Brehm JM, Celedon JC, Soto-Quiros ME, et al. Serum vitamin D levels and markers of severity of childhood asthma in Costa Rica. Am J Respir Crit Care Med 2009;179:765-71.

12. Mansbach JM, Camargo CA Jr. Respiratory viruses in bronchiolitis and their link to recurrent wheezing and asthma. Clin Lab Med 2009;29:741-55.

13. Cannell JJ, Zasloff M, Garland CF, Scragg R, Giovannucci E. On the epidemiology of influenza. Virol J 2008;5:29.

14. Hope-Simpson RE. The role of season in the epidemiology of influenza. J Hyg (Lond) 1981;86:35-47.

15. Wayse V, Yousafzai A, Mogale K, Filteau S. Association of subclinical vitamin $D$ deficiency with severe acute lower respiratory infection in Indian children under 5 y. Eur J Clin Nutr 2004;58:563-7.

16. Najada AS, Habashneh MS, KhadeR M. Thefrequency of nutritional rickets among hospitalized infants and its relation to respiratory diseases. J Trop Pediatr 2004;50:364-8.

17. Walker VP, Modlin RL. The vitamin D connection to pediatric infections and immune function. Pediatr Res 2009;65:106R13R.

18. Sutherland ER, Goleva E, Jackson LP, Stevens AD, Leung DY. Vitamin D levels, lung function, and steroid response in adult asthma. Am J Respir Crit Care Med 2010;181:699-704.

19. Kovacs CS. Vitamin D in pregnancy and lactation: maternal, fetal, and neonatal outcomes from human and animal studies. Am J Clin Nutr 2008;88:520S-8S.

20. Karatekin G, Kaya A, Salihoğlu O, Balci H, Nuhoğlu A. Association of subclinical vitamin $D$ deficiency in newborns with acute lower respiratory infection and their mothers. Eur J Clin Nutr 2009;63:473-7.

21. Muhe L, Lulseged $S$, Mason KE, Simoes EA. Case control study of the role of nutritional rickets in the risk of developing pneumonia in Ethiopian children. Lancet 1997;349:1801-4.

22. Banajeh SM, al-Sunbali NN, al-Sanahani SH. Clinical characteristics and outcome of children aged under 5 years hospitalized with severe pneumonia in Yemen. Ann Trop Paediatr 1997;17:321-6. 